doi: $10.2306 /$ scienceasia1513-1874.2012.38.227

\title{
The effects of herbivore exclusion and nutrient enrichment on growth and reproduction of Halimeda macroloba
}

\author{
Jaruwan Mayakun $^{\mathrm{a}}$, Jeong Ha Kim ${ }^{\mathrm{b}}$, Brian E. Lapointe ${ }^{\mathrm{c}}$, Anchana Prathep ${ }^{\mathrm{a}, *}$ \\ a Seaweed and Seagrass Research Unit, Excellence Centre for Biodiversity of Peninsular Thailand, \\ Department of Biology, Faculty of Science, Prince of Songkla University, Hat Yai, Songkhla, \\ Thailand. 90112 \\ b Department of Biological Science, Sungkyunkwan University, Suwon, South Korea. 440-746 \\ c Marine Ecosystem Health Program, Harbor Branch Oceanographic Institute at Florida Atlantic University, \\ Ft. Pierce, FL 34946, USA
}

*Corresponding author, e-mail: anchana.p@psu.ac.th

Received 18 Apr 2012

Accepted 26 Aug 2012

\begin{abstract}
The questions on how Halimeda macroloba allocates resources to growth and sexual reproduction when encountering herbivores and elevated nutrient concentrations were experimentally examined in the natural subtidal zone and in water tanks. The field experimental design comprised 96 plots $\left(50 \times 50 \mathrm{~cm}^{2}\right)$, with and without herbivores, and two nutrient levels. Cages were used to exclude fish herbivores: uncaged plots and fully caged plots; and 2 nutrient levels were manipulated: enriched and ambient levels in order to determine the effect of nutrients. Osmocote slow-release fertilizer was placed in each enriched plot. For the outdoor water tank experiments, mechanical clipping was used to simulate grazing on algae. Nutrient enrichment had a positive effect on the growth and reproduction of H. macroloba both in the field and water tank experiments, and herbivory or simulation of grazing did have a significant effect on the growth of algae in the water tank experiments. H. macroloba produced gametangia within 1-2 weeks after nutrient enrichment, to indicate that enrichment might be the trigger for reproduction of $H$. macroloba. From the tissue nutrient levels, the C:N, C:P, and N:P $(18.9,639$, and 33.7) ratios indicated that the productivity of $H$. macroloba was phosphorus limited.
\end{abstract}

KEYWORDS: herbivory, alga, coral reef, resource allocation

\section{INTRODUCTION}

During the past several decades, phase shifts from coral- to algal-dominated communities on tropical reefs have become increasingly common ${ }^{1-4}$. Phase shifts have been caused by natural and anthropogenic disturbances, for example a decline in herbivory has increased nutrient availability and mass coral bleaching. Thus top-down (herbivory) and bottomup (nutrient) factors have been implicated in phase shifts ${ }^{3-5}$. Algal responses at the community-level to top-down and bottom-up have been determined. Herbivory influences the abundance, the functional composition of algae and marine macroalgal community structures ${ }^{6-13}$. Algal community diversity is affected by the clearing of substratum for new individuals ${ }^{14}$. Herbivores can also shift the pattern and alter rates of algal succession ${ }^{15-18}$. Increased nutrient availability can increase macroalgal growth, biomass, and primary productivity ${ }^{1,19,20}$. However, the effects of these factors at the level of individuals are less well-known: such as how algae respond and allocate resources between their life-history traits such as growth and reproduction.

An understanding of the roles of herbivory and nutrient at the algal individual level would be of more benefit than at the community level because of the great variability in time and space ${ }^{21}$. Hence a study at the individual-level is becoming critical and challenging. It may reveal how algae cope or respond to stress or environmental changes at the individual level.

In recent years, macroalgae especially Halimeda have become a dominant component of many reefs in the tropical regions of the Pacific Ocean, Indian Ocean, and especially Thai waters, through increasing their cover, biomass and abundance. The increasing cover of Halimeda has been documented in many reefs such as coral reefs in Jamaica ${ }^{22}$ and the Florida Keys ${ }^{23,24}$. Halimeda is abundant and widely distributed because it is a successful competitor with a high growth rate ${ }^{24-26}$. It is of great importance 
in a broad range of ecological systems, including reef construction and production of calcium carbonate sand $^{23}$. However, ongoing ocean acidification has been suggested to have a negative effect on calcification of $H$. macroloba by decreasing the calcium carbonate crystal width and reducing photosynthesis ${ }^{27}$. This might cause the loss of this calcified green alga, H. macroloba, which is the major producer of calcium carbonate sands.

In this study, Halimeda macroloba Decaisne (Chlorophyta: Halimedaceae) was chosen as a model organism to test the effects of herbivore exclusion and nutrient enrichment on resource allocation on growth and reproduction. It was predicted that where there is nutrient enrichment, algae should allocate more resources to growth and reproduction. An experiment was designed to address the following questions: (1) Do herbivore exclusion and nutrient enrichment influence growth and reproduction of $H$. macroloba? (2) How do algae allocate the resources to growth and sexual reproduction in response to exclusion of herbivores and nutrient enrichment?

\section{MATERIALS AND METHODS}

The experimental site was situated in the shallow (2-3 m in depth) coastal waters at $\mathrm{Ko} \mathrm{Rab}, \mathrm{Mu}$ Ko Thale Tai National Park $\left(9^{\circ} 19^{\prime} 20^{\prime \prime}\right.$ N, $99^{\circ} 46^{\prime}$ $80^{\prime \prime} \mathrm{E}$ ), Gulf of Thailand. The climate of this area is tropical and under monsoonal influence. There are two dominant seasons, a dry season dominated by Southwest Monsoon (February-April) and a rainy season predominated by Northeast Monsoon (MayJanuary) with a major rain peak in November. The average rainfall varies from $8.1-302.0 \mathrm{~mm}$ and the sea surface water temperature varies from $27-30^{\circ} \mathrm{C}$. The salinity varies between 29 and 32 ppt. The maximum and minimum tidal ranges for the Ko Samui coast are about 3.0 and $0.8 \mathrm{~m}$, respectively. The tides are semidiurnal. In this area, approximately 70 species of coral reef fish are found. The dominant herbivorous fishes are parrotfish, surgeonfish, and damselfish.

The relative importance of herbivore exclusion and nutrient enrichment on algal growth and reproduction were experimentally tested in a factorial design in the field and in an outdoor water tank at the Department of Biology, Faculty of Science, Prince of Songkla University.

\section{Field experiment}

Each plot $(50 \mathrm{~cm} \times 50 \mathrm{~cm})$ was permanently marked using thread and labelled and plots were placed a maximum of 1 or $2 \mathrm{~m}$ apart. The larger and older algae were removed to eliminate variances in the density and algae age between plots and leaving 30 young mature plants, mean length was $9.4 \pm 0.87 \mathrm{~cm}$ (mean $\pm \mathrm{SE}$ ). There were 2 categories of nutrient situations: enriched and ambient; and 2 categories of herbivory: with and without herbivores. There were a total of four treatment combinations.

The plots were fertilized using Osmocote, a slowrelease fertilizer; $60 \mathrm{~g}$ of fertilizer (14-14-14, N-P-K) were enclosed in three mesh bags constructed from nylon hosiery. The bags were placed in the centre and at two diagonal corners of each nutrient-enriched plot. The bags were changed every 2 weeks. The rates of nutrient release were estimated by drying the bags after 1 and 2 weeks of exposure, weighing the bags again, and calculating the mass lost ${ }^{11}$. This fertilizer treatment potentially doubled nutrient concentrations relative to ambient levels. The ambient phosphate and nitrate concentrations were $0.47 \pm 0.04$ and $0.07 \pm 0.02 \mathrm{mg} / \mathrm{l}$, respectively (Mayakun, unpublished data).

Cages were used to exclude herbivorous fishes; the cage size was $50 \mathrm{~cm} \times 50 \mathrm{~cm} \times 50 \mathrm{~cm}$ and cages were made of a stainless steel frame covered with $2 \mathrm{~cm} \times 2 \mathrm{~cm}$ wire mesh allowing the water circulation but excluding the herbivorous fishes. All cages were fixed on the substrate with concrete nails. Cages were cleaned using brushes to remove attached algae or settling organisms and damaged cages were replaced occasionally. Light intensity inside and outside cages were measured using the Onset-Hobo LI light logger.

The experiments were divided into 4 treatments: (1) cage and ambient nutrient, (2) cage and enriched nitrogen and phosphorus, (3) uncaged and ambient nutrient, (4) uncaged and enriched nitrogen and phosphorus. There were 96 plots in total and three plots were collected in each time.

All experimental manipulations were performed in May 2008. A total of 30 algal thalli in each plot were observed biweekly, collected and brought back to the laboratory for growth, number of reproductive thalli, and $\mathrm{C}: \mathrm{N}$ : $\mathrm{P}$ ratio measurements.

\section{Water-tank experiment}

The experiment was conducted in February 2009 in 48 outdoor water tanks, with a volume of 501 each. H. macroloba (length was $9.4 \pm 0.87 \mathrm{~cm}$ $($ mean $\pm \mathrm{SE})$ ) were collected from the field and cleaned of all visible epibionts, rinsed several times with seawater, and transported to the laboratory in seawater. Each of 20 young thalli was transplanted in each water tank and anchored at the bottom with sand. Water circulation was provided using a filter pump (20-106 GPH, adjustable flow rate) that was 
placed in each water tank. The water tanks were situated outdoors in natural light conditions. Total light intensity at noon averaged $1444 \pm 333 \mu \mathrm{mol}$ $\mathrm{m}^{-2} \mathrm{~s}^{-1}$. Water temperature and salinity varied within $27-32{ }^{\circ} \mathrm{C}$ and $31-33$ psu, respectively. For simulated grazing on algae, mechanical clipping was used to mimic the naturally occurring damage, caused by herbivorous fishes. Clipping damage was distributed over the vegetative tissue of each thallus and tissues were clipped every 3 days.

Nutrients levels were manipulated into 2 levels: enriched (enriched nitrogen and phosphorus) and ambient levels. In the enriched tanks, Osmocote, a slowrelease fertilizer (14-14-14, N-K-P), was enclosed in mesh bags made from nylon hosiery, each containing $60 \mathrm{~g}$ of fertilizer.

The experiments were divided into 4 treatments: (1) no clipping and ambient nutrient (controls), (2) no clipping and enriched nitrogen and phosphorus, (3) clipping and ambient nutrient, (4) clipping and enriched nitrogen and phosphorus. There were 48 tanks in total and three plots were collected in each time.

\section{The measurements}

Biomass (wet and dry weight), the maximum length (holdfast to segment apex), the length of the longest segment, the width of the segment of the stipe, number of segments, holdfast and stipe diameter of all plants were measured.

Tissue nutrient concentrations (carbon, nitrogen, and phosphorus content) in the vegetative tissues of collected and dried algae were measured. Macroalgae were collected from each plot and placed in Ziploc bags, returned to the laboratory, cleaned of sediment, epiphytes, and then wet-weighed and dried in an oven $\left(65^{\circ} \mathrm{C}\right)$ to constant weight. The dried algae were ground to a fine powder with a mortar and pestle and subsequently analysed for $\mathrm{C}: \mathrm{N}: \mathrm{P}$ ratios at the Central Analytical Centre, Faculty of Natural Resources, Prince of Songkla University, Hat Yai, Thailand. Also, changes in dry weight of both algae were used to calculate specific growth rates (doublings $\mathrm{d}^{-1}$ ) ${ }^{28}$ as:

$$
\mu=\frac{3.32 \log _{10}\left(N / N_{0}\right)}{\Delta t},
$$

where $N_{0}$ is the initial biomass and $N$ is the final biomass with time $(\Delta t)$.

Reproductive events of $H$. macroloba in each plot were observed and recorded. Fertile H. macroloba were collected and preserved in $4 \%$ formaldehyde in seawater for later examination. Reproductive occurrences were recorded and gametangial characteristics were observed. The structure and size of the reproductive organs were measured. The width and length of the gametangia and gametophore were measured. The gametophores were cut off with a blade and measured and recorded using a colour digital camera attached to a compound microscope (Model: BX 51TF Olympus, No. 1H20773, Japan).

\section{Data analysis}

A 3-way ANOVA was used to examine the effects of the fixed factors: (1) herbivory, (2) nutrient, and (3) sampling times on algal growth and reproduction. The Cochran's $C$-test was used to determine the homogeneity of variances. In cases of violation, a $\log (x+1)$ transformation was made prior to analysis. Differences among the mean effects of herbivores and nutrients at each sampling time and between treatments were tested with Turkey's HSD test. All statistical analyses were made using the computer program SPSS for Windows version 11.5.

\section{RESULTS}

\section{Field experiment}

Light intensity: In the field, there were no important differences in light intensity between the caged and uncaged plots ( $t$-test, $p=0.343)$. Cages decreased total light intensity by around $15-20 \%$. Maximum light intensity was $1963 \mu \mathrm{mol} \mathrm{m} \mathrm{m}^{-2} \mathrm{~s}^{-1}$ inside cages and $2331 \mu \mathrm{mol} \mathrm{m} \mathrm{m}^{-2} \mathrm{~s}^{-1}$ outside cages. This light intensity was much greater than the level needed for saturation of the photosynthetic rate of a broad variety of algae ${ }^{29}$. Hence we assumed that the lower intensity in the cages did not affect the growth and reproduction.

Nutrient enrichment: The enriched nutrient significantly increased the growth of $H$. macroloba, by influencing the holdfast and stipe diameter $(p=$ 0.013, $p=0.032$; Table 1). All other terms of the growth measurements with regard to thallus length and blade length were not significantly different $(P>$ $0.05)$. In addition, the growth of $H$. macroloba varied significantly through time during this study (Table 1). At 2-3 wks, Halimeda tended to respond to enriched nutrient, as it increased in biomass and number of segments (Fig. 1).

The specific growth rate of $H$. macroloba increased from 0.02 doublings $\mathrm{d}^{-1}$ at the ambient plots to 0.08 doublings $\mathrm{d}^{-1}$ at the enriched plots. Halimeda quickly produced new segments around 1-2 segments per day. For the C:N:P ratios, there was a nutrient effect on the C:N, C:P, and N:P ratios of H. macroloba (Table 2). The $\mathrm{C}: \mathrm{P}$ and $\mathrm{N}: \mathrm{P}$ ratios tended to decrease 
Table 1 The effects of nutrient enrichment and herbivore exclusion on growth measurement of $H$. macroloba from the field experiment.

\begin{tabular}{|c|c|c|c|c|c|c|c|c|c|}
\hline \multirow[b]{3}{*}{ Source } & \multicolumn{9}{|c|}{ H. macroloba } \\
\hline & \multicolumn{3}{|c|}{ Thallus length } & \multicolumn{3}{|c|}{ Blades length } & \multicolumn{3}{|c|}{ Dry weight of thallus } \\
\hline & $\mathrm{df}$ & MS & $\mathrm{F}$ & df & MS & $\mathrm{F}$ & df & MS & $\mathrm{F}$ \\
\hline Time & 2 & 1.440 & $31.019^{\text {**** }}$ & 2 & 1.152 & $27.888^{\text {***** }}$ & 2 & 0.375 & $14.859^{* * *}$ \\
\hline Nutrient & 1 & 0.000 & $0.006^{\mathrm{ns}}$ & 1 & 0.001 & $0.035^{\mathrm{ns}}$ & 1 & 0.027 & $1.074^{\mathrm{ns}}$ \\
\hline Herbivore & 1 & 0.067 & $1.441^{\mathrm{ns}}$ & 1 & 0.001 & $0.020^{\mathrm{ns}}$ & 1 & 0.003 & $0.124^{\mathrm{ns}}$ \\
\hline Time $\times$ nutrient & 2 & 0.004 & $0.089^{\mathrm{ns}}$ & 2 & 0.010 & $0.237^{\mathrm{ns}}$ & 2 & 0.019 & $0.757^{\mathrm{ns}}$ \\
\hline Time $\times$ herbivore & 2 & 0.406 & $8.745^{* *}$ & 2 & 0.356 & $8.607^{* *}$ & 2 & 0.126 & $4.980^{*}$ \\
\hline Nutrient $\times$ herbivore & 1 & 0.001 & $0.018^{\mathrm{ns}}$ & 1 & 0.017 & $0.403^{\mathrm{ns}}$ & 1 & 0.010 & $0.386^{\mathrm{ns}}$ \\
\hline Time $\times$ nutrient $\times$ herbivore & 2 & 0.147 & $3.168^{\mathrm{ns}}$ & 2 & 0.099 & $2.391^{\mathrm{ns}}$ & 2 & 0.036 & $1.431^{\mathrm{ns}}$ \\
\hline Error & 22 & 0.046 & & 22 & 0.041 & & 22 & 0.025 & \\
\hline \multirow[t]{3}{*}{ Total } & 34 & & & 34 & & & 34 & & \\
\hline & \multicolumn{9}{|c|}{ H. macroloba } \\
\hline & \multicolumn{3}{|c|}{ Holdfast diameter } & \multicolumn{3}{|c|}{ Stipe diameter } & \multicolumn{3}{|c|}{ Number of segments } \\
\hline Source & df & MS & $\mathrm{F}$ & df & MS & $\mathrm{F}$ & df & MS & $\mathrm{F}$ \\
\hline Time & 2 & 0.098 & $1.345^{\mathrm{ns}}$ & 2 & 0.316 & $4.37^{*}$ & 2 & 6.299 & $21.113^{\text {*** }}$ \\
\hline Nutrient & 1 & 0.531 & $7.281^{*}$ & 1 & 0.378 & $5.231^{*}$ & 1 & 0.524 & $1.757^{\mathrm{ns}}$ \\
\hline Herbivore & 1 & 0.511 & $7.003^{*}$ & 1 & 0.07 & $0.972^{\mathrm{ns}}$ & 1 & 0.004 & $0.014^{\mathrm{ns}}$ \\
\hline Time $\times$ nutrient & 2 & 0.066 & $0.909^{\mathrm{ns}}$ & 2 & 0.07 & $0.964^{\mathrm{ns}}$ & 2 & 0.091 & $0.305^{\mathrm{ns}}$ \\
\hline Time $\times$ herbivore & 2 & 0.344 & $4.716^{*}$ & 2 & 0.143 & $1.981^{\mathrm{ns}}$ & 2 & 1.502 & $5.034^{*}$ \\
\hline Nutrient $\times$ herbivore & 1 & 0.002 & $0.022^{\mathrm{ns}}$ & 1 & 0.042 & $0.583^{\mathrm{ns}}$ & 1 & 0.206 & $0.691^{\mathrm{ns}}$ \\
\hline Time $\times$ nutrient $\times$ herbivore & 2 & 0.086 & $1.182^{\mathrm{ns}}$ & 2 & 0.09 & $1.240^{\mathrm{ns}}$ & 2 & 0.322 & $1.078^{\mathrm{ns}}$ \\
\hline Error & 22 & 0.073 & & 22 & 0.072 & & 22 & 0.298 & \\
\hline Total & 34 & & & 34 & & & 34 & & \\
\hline
\end{tabular}

$* p<0.05 ; * * p<0.01 ; * * * p<0.001 ;$ ns: not significant.

Table 2 Tissue levels (\% dry wt.) of the C:N, C:P, and N:P of $H$. macroloba from enriched plots in the field experiment (Values in parentheses $=\mathrm{SE}, \mathrm{n}=90$ thallus of each treatment and sampling time).

\begin{tabular}{lccc}
\hline Time & \multicolumn{3}{c}{ H. macroloba } \\
\cline { 2 - 4 } & $\mathrm{C}: \mathrm{N}$ & $\mathrm{C}: \mathrm{P}$ & $\mathrm{N}: \mathrm{P}$ \\
\hline Initial & 18.9 & 639 & 33.7 \\
& $(1.56)$ & $(218)$ & $(10.6)$ \\
Week 1 & 19.4 & 726 & 37.9 \\
& $(1.23)$ & $(31.8)$ & $(3.21)$ \\
Week 3 & 21.3 & 362 & 18.2 \\
& $(3.66)$ & $(28.6)$ & $(3.53)$ \\
\hline
\end{tabular}

through time after enrichment, and indicated that the productivity of $H$. macroloba was phosphorus limited.

Halimeda rapidly reproduced within 1-2 weeks after nutrient enrichment. The result showed that nutrient enrichment can trigger the reproduction of $H$. macroloba; 5 reproductive thalli were found in the enriched plots. Only 1 reproductive thallus was collected from the ambient plot.
The effect of herbivory: Herbivory had an effect on holdfast diameter and there was a significant interaction between time $\times$ herbivory on the growth measurements regarding thallus length $(p=0.002)$, blade length $(p=0.002)$, dry weight of thallus $(p=$ $0.016)$, holdfast diameter $(p=0.020)$ and number of segments $(p=0.016$; Table 1$)$.

For the reproductive events, no reproductive individual of $H$. macroloba was found in any plots.

\section{Water tank experiment}

Nutrient enrichment: The enriched nutrient had a significant effect on the growth of $H$. macroloba, with a significant increase of thallus length, blade length, and number of segments $(p<0.001, p<0.001, p=$ 0.007; Table 3). All other terms of growth measurements regarding the dry weight of the thallus, holdfast and stipe diameter were not significantly different $(P>0.05)$. For interactions, there were no significant interactions between time and nutrient for any growth measures $(P>0.05$; Table 3$)$. At $1 \mathrm{wk}$, Halimeda tended to respond to enriched nutrient, increasing in biomass and in the number of segments (Fig. 2). 
Table 3 The effects of clipping and nutrient enrichment on growth measurement of $H$. macroloba from the laboratory experiments.

\begin{tabular}{|c|c|c|c|c|c|c|c|c|c|}
\hline \multirow[b]{3}{*}{ Source } & \multicolumn{9}{|c|}{ H. macroloba } \\
\hline & \multicolumn{3}{|c|}{ Thallus length } & \multicolumn{3}{|c|}{ Blades length } & \multicolumn{3}{|c|}{ Dry weight of thallus } \\
\hline & df & MS & $\mathrm{F}$ & $\mathrm{df}$ & MS & $\mathrm{F}$ & df & MS & $\mathrm{F}$ \\
\hline Time & 2 & 0.012 & $1.036^{\mathrm{ns}}$ & 2 & 0.046 & $4.699^{*}$ & 2 & 0.020 & $2.425^{\mathrm{ns}}$ \\
\hline Nutrient & 1 & 0.496 & $43.713^{\text {*** }}$ & 1 & 0.383 & $38.803^{* * *}$ & 1 & 0.000 & $0.057^{\mathrm{ns}}$ \\
\hline Herbivore & 1 & 0.698 & $61.573^{\text {**** }}$ & 1 & 0.350 & $35.470^{\text {**** }}$ & 1 & 0.008 & $0.959^{\mathrm{ns}}$ \\
\hline Time $\times$ nutrient & 2 & 0.013 & $1.184^{\mathrm{ns}}$ & 2 & 0.007 & $0.694^{\mathrm{ns}}$ & 2 & 0.007 & $0.846^{\mathrm{ns}}$ \\
\hline Time $\times$ herbivore & 2 & 0.004 & $0.371^{\mathrm{ns}}$ & 2 & 0.001 & $0.109^{\mathrm{ns}}$ & 2 & 0.031 & $3.80^{*}$ \\
\hline Nutrient $\times$ herbivore & 1 & 0.184 & $16.262^{\text {**** }}$ & 1 & 0.132 & $13.422^{* * *}$ & 1 & 0.002 & $0.265^{\mathrm{ns}}$ \\
\hline Time $\times$ nutrient $\times$ herbivore & 2 & 0.011 & $0.972^{\mathrm{ns}}$ & 2 & 0.013 & $1.360^{\mathrm{ns}}$ & 2 & 0.097 & $11.970^{* * *}$ \\
\hline Error & 21 & 0.011 & & 21 & 0.010 & & 21 & 0.008 & \\
\hline \multirow[t]{3}{*}{ Total } & 33 & & & 33 & & & 33 & & \\
\hline & \multicolumn{9}{|c|}{ H. macroloba } \\
\hline & \multicolumn{3}{|c|}{ Holdfast diameter } & \multicolumn{3}{|c|}{ Stipe diameter } & \multicolumn{3}{|c|}{ Number of segments } \\
\hline Source & df & MS & $\mathrm{F}$ & df & MS & F & df & MS & $\mathrm{F}$ \\
\hline Time & 2 & 0.011 & $0.191^{\mathrm{ns}}$ & 2 & 0.011 & $0.366^{\mathrm{ns}}$ & 2 & 0.413 & $0.980^{\mathrm{ns}}$ \\
\hline Nutrient & 1 & 0.042 & $0.717^{\mathrm{ns}}$ & 1 & 0.001 & $0.045^{\mathrm{ns}}$ & 1 & 3.718 & $8.824^{* *}$ \\
\hline Herbivore & 1 & 0.501 & $8.631^{* *}$ & 1 & 0.093 & $3.024^{\mathrm{ns}}$ & 1 & 6.424 & $15.246^{* * * *}$ \\
\hline Time $\times$ nutrient & 2 & 0.035 & $0.607^{\mathrm{ns}}$ & 2 & 0.014 & $0.465^{\mathrm{ns}}$ & 2 & 0.127 & $0.302^{\mathrm{ns}}$ \\
\hline Time $\times$ herbivore & 2 & 0.033 & $0.571^{\mathrm{ns}}$ & 2 & 0.089 & $2.907^{\mathrm{ns}}$ & 2 & 0.449 & $1.065^{\mathrm{ns}}$ \\
\hline Nutrient $\times$ herbivore & 1 & 0.011 & $0.192^{\mathrm{ns}}$ & 1 & 0.016 & $0.507^{\mathrm{ns}}$ & 1 & 2.391 & $5.676^{*}$ \\
\hline Time $\times$ nutrient $\times$ herbivore & 2 & 0 & $0.006^{\mathrm{ns}}$ & 2 & 0.126 & $4.117^{*}$ & 2 & 0.095 & $0.225^{\mathrm{ns}}$ \\
\hline Error & 21 & 0.058 & & 21 & 0.031 & & 21 & 0.421 & \\
\hline Total & 33 & & & 33 & & & 33 & & \\
\hline
\end{tabular}

$* p<0.05 ; * * p<0.01 ; * * * p<0.001 ;$ ns: not significant.

The specific growth rate of $H$. macroloba increased from 0.03 doublings $\mathrm{d}^{-1}$ at the ambient treatments to 0.04 doublings $\mathrm{d}^{-1}$ at the enriched treatments. In the water tank experiments, Halimeda produced around 3 new segments per day, producing more segments than Halimeda in the field.

For the C:N:P ratios, there was a nutrient effect on the C:N, C:P, and $\mathrm{N}: \mathrm{P}$ ratios of $H$. macroloba (Table 4). The C:P and N:P ratios tended to decrease through time after nutrients were enriched, and indicated that the productivity of $H$. macroloba is phosphorus limited, but the $\mathrm{C}: \mathrm{N}$ ratio trend was to increase when nutrients were enriched.

Halimeda reproduced within 2 weeks after nutrients were added. Five individual reproductive thalli were found in the both nitrogen and phosphorus treatments.

Clipping (herbivory): Herbivory had a significant positive effect on the growth of $H$. macroloba; it affected thallus length $(p<0.001)$, blade length ( $p<0.001)$, holdfast $(p=0.008)$, and the number
Table 4 Tissue levels (\% dry wt.) of C:N, C:P, and N:P of H. macroloba from enriched plots in the laboratory (Values in parentheses $=S E, n=60$ thallus of each treatment and sampling time).

\begin{tabular}{lccc}
\hline Time & \multicolumn{3}{c}{ H. macroloba } \\
\cline { 2 - 4 } & $\mathrm{C}: \mathrm{N}$ & $\mathrm{C}: \mathrm{P}$ & $\mathrm{N}: \mathrm{P}$ \\
\hline Initial & 16.6 & 737 & 33.4 \\
& $(2.13)$ & $(290)$ & $(10.4)$ \\
Enriched + No clipping & 19.1 & 429 & 23.6 \\
& $(2.43)$ & $(33.8)$ & $(8.54)$ \\
Enriched + Clipping & 22.6 & 296 & 16.2 \\
& $(4.29)$ & $(70.8)$ & $(2.21)$ \\
\hline
\end{tabular}

of segments ( $p=0.001$; Table 3$)$. There were no significant interactions between time and herbivore for growth measurements except for the dry weights of the thallus ( $p=0.039$; Table 3$)$. The specific growth rate of Halimeda at the enriched treatments with clipping increased up to 0.09 doublings $\mathrm{d}^{-1}$ from 0.03 doublings $\mathrm{d}^{-1}$ at the ambient treatments. Thus 

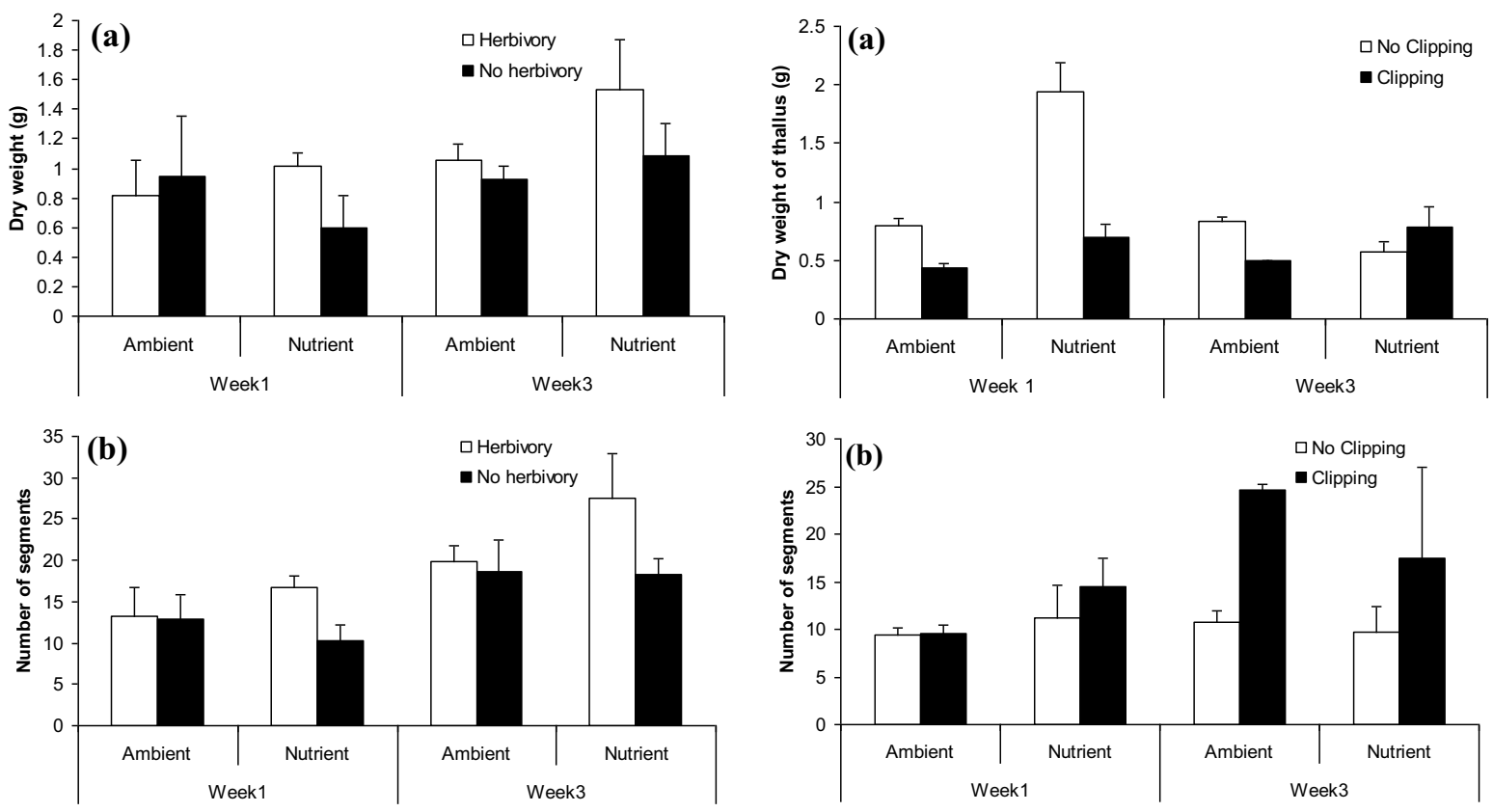

Fig. 1 The effects of herbivory and nutrient enrichment on (a) the dry weight of thallus and (b) number of segments of $H$. macroloba from the field experiment. Data are means $\pm S E$ of 90 algal thallus of each treatment and sampling time.

H. macroloba had greater specific growth rate when algae were in the combined condition; for the enriched together with clipping treatments, the growth rate was 2.25 times faster than the enriched with no clipping treatments, 0.04 doublings $\mathrm{d}^{-1}$.

No reproductive individual of $H$. macroloba was found in any treatments with and without clipping.

\section{DISCUSSION}

\section{The effect of nutrient enrichment}

H. macroloba showed positive responses to nutrient enrichment, including growth, reproduction, and tissue nutrient. Nutrient enrichment tended to affect only the holdfast and stipe diameter. The uptake ability from nutrients in the sediment might have an effect on holdfast and stipe diameter. It might be because of the unique bulbous holdfast that can attach to the substratum and take up nutrients directly from the sediments ${ }^{30}$, Halimeda invested more energy reserves in producing new upright segments.

In this study, extra nutrients produced a significant increase on the growth compared to the ambient plots, as shown in the growth rate and the C:N:P ratios. After nutrient enrichment, the $\mathrm{C}: \mathrm{N}: \mathrm{P}$ ratios of Halimeda decreased, to indicate that the productivity

Fig. 2 The effects of clipping and nutrient enrichment on (a) the dry weight of thallus and (b) number of segments of $H$. macroloba from the laboratory experiment. Data are means $\pm S E$ of 60 algal thallus of each treatment and sampling time.

of H. macroloba is phosphorus limited. Phosphorus limitation is a common phenomenon on coral reefs such as on Jamaica reefs ${ }^{1}$, and a high level of phosphorus on reefs can inhibit coral calcification and growth rates but increase algal biomass ${ }^{2}$. The growth rate of Halimeda was 2.25 times faster after enrichment with the clipping condition than with the nonclipping condition. Therefore, it seems that Halimeda needs an external nutrient treatment to respond to the clipping treatment. Also, Halimeda responded to the clipping condition by increasing its growth. This work supports the $r$-selected species hypothesis. We suggest that the $r$-species have a fast growing rate and might respond quickly within a few days to environmental changes and stresses. In contrast, Fong et $\mathrm{al}^{30}$ found that $H$. incrassata did not respond to nutrient enrichment in a 3-d experiment but this may be due to its short duration or adaptation to sediment nutrient supply. Our results were the opposite with a quick response in growth rate. However, nutrients are known to affect the growth of Halimeda. The studies at Florida Keys have found that Halimeda responded positively to nutrient enrichment by increases in its growth rates ${ }^{26,31}$.

For the reproduction response, $H$. macroloba reproduced within 1-2 weeks when nutrients were 
added both in the field and water tank experiments. Mayakun et $\mathrm{al}^{32}$ indicated that nutrient enrichment can trigger the reproduction of $H$. macroloba. Similarity in higher plants, nutrient availability has been shown to affect plant growth rate and influence the time of reproduction in plants. The elevated nutrient concentration might increase the reproduction and the fecundity in algae that reproduce throughout the year ${ }^{33}$.

Because of its ability to take up nutrient, grow, and reproduce, H. macroloba is a common and abundant alga in this area. In addition, the nutrient enrichment seems to be the important feature determining the dynamics of $H$. macroloba.

\section{The effect of herbivory}

In this study, there was no strong effect of herbivory possibly because of the calcification of Halimeda segments, which would deter herbivory by making the alga harder and more difficult to bite. The presence of chemical deterrents also renders algae less palatable and digestible to herbivores. Newly young green segments would be easy to bite and attractive to herbivorous fishes ${ }^{34}$ while herbivores avoid grazing on reproductive cells of Halimeda because of secondary metabolites. However, herbivores (and clipping) did have a significant effect on the growth of algae in the field and the water tank experiments. This might be due to the high intensity and continuous clipping. The artificial clipping was intended to simulate herbivory and induced increase in growth; and this was paralleled in the field experiment where actual grazing took place. Herbivory and clipping would cause wounding; however, Halimeda rapidly plugged over a wound, formed a new cell wall to mitigate the impact of grazing (or clipping) and then initiated new segments. This might increase the growth of H. macroloba. In contrast, Dethier et al ${ }^{35}$ suggested that herbivory had negative effects on growth and reproduction of Fucus gardneri by consuming receptacle tissues.

Our results did not provide evidence that herbivorous fishes will affect reproduction of Halimeda in the field. This might be because of the intensity and frequency of bites and the existence of more preferable food sources in the field.

In conclusion, in the field herbivory had no effect on the reproduction of $H$. macroloba while nutrients had. At the individual-level responses, Halimeda allocated resources to the growth and reproduction in response to nutrient enrichment that led to an increase in biomass and abundance. Increases of nutrient do increase growth and biomass of Halimeda and that can be a causal factor driving phase shifts on coral reefs ${ }^{1,19,20}$. In Thai waters, Halimeda has become a dominant component of many reefs, increasing their cover, biomass and abundance. The responses of Halimeda at the individual, population, and community levels are supported by nutrient. Thus we can predict that the growth and abundance of Halimeda will increase with nutrient enrichment and nutrient is one of the factors that influences Halimeda and can drive phase shifts on reefs.

Acknowledgements: This study is part of the doctoral dissertation research of Jaruwan Mayakun at the Prince of Songkla University (PSU), Thailand. The first author would like to thank the members of Seaweed \& Seagrass Research Unit team, PSU for their help in the field. Financial support from the Thailand Research Fund through the Royal Golden Jubilee Ph.D. Programme (Grant No. PHD/0063/2550) to Jaruwan Mayakun and Anchana Prathep is acknowledged. This work was also partly funded by the Graduate School, PSU. Thanks also to Dr Brian Hodgson for assistance with the English.

\section{REFERENCES}

1. Lapointe BE (1997) Nutrient thresholds for bottom-up control of macroalgal blooms on coral reefs in Jamaica and southeast Florida. Limnol Oceanogr 42, 1119-31.

2. Stimson J, Larned ST, Conklin E (2001) Effects of herbivory, nutrient levels, and introduced algae on the distribution and abundance of the invasive macroalga Dictyosphaeria cavernosa in Kaneohe Bay, Hawaii. Coral Reefs 19, 343-57.

3. Burkepile DE, Hay ME (2006) Herbivore versus nutrient control of marine primary producers: contextdependent effects. Ecology 87, 3128-39.

4. Idjadi JA, Lee SC, Bruno JF, Precht WF, Allen-Requa L, Edmunds PJ (2006) Rapid phase-shift reversal on a Jamaican coral reef. Coral Reefs 25, 209-11.

5. Littler MM, Littler DS (1984) Models of tropical reef biogenesis: the contribution of algae. Prog Phycol Res 3, 323-64.

6. Sousa WP (1979) Experimental investigations of disturbance and ecological succession in a rocky intertidal algal community. Ecol Monogr 49, 227-54.

7. Lubchenco J, Gaines SD (1981) A unified approach to marine plant-herbivore interactions. I. Populations and communities. Annu Rev Ecol Systemat 12, 405-37.

8. Sammarco PW (1983) Effects of fish grazing and damselfish territoriality on coral reef algae. I. Algal community structure. Mar Ecol Progr 13, 1-14.

9. Littler MM, Littler DS (1985) Handbook of Phycological Methods: Ecological Field Methods: Macroalgae. Cambridge Univ Press, New York.

10. Hay ME (1997) The ecology and evolution of seaweedherbivore interactions on coral reefs. Coral Reefs 16, S67-76. 
11. Thacker RW, Ginsburg DW, Paul VJ (2001) Effects of herbivore exclusion and nutrient enrichment on coral reef macroalgae and cyanobacteria. Coral Reefs 19, 318-29.

12. Belliveau SA, PaulVJ (2002) Effects of herbivory and nutrients on the early colonization of crustose coralline and fleshy algae. Mar Ecol Progr 232, 105-14.

13. McClanahan TR, Karnauskas M (2011) Relationships between benthic cover, current strength, herbivory, and a fisheries closure in Glovers Reef Atoll, Belize. Coral Reefs 30, 9-19.

14. Menge BA, Lubchenco J (1981) Community organization in temperate and tropical rocky intertidal habitats: prey refuges in relation to consumer pressure gradients. Ecol Monogr 51, 429-50.

15. Hixon MA, BrostoffWN (1996) Succession and herbivory: effects of differential fish grazing on Hawaiian coral-reef algae. Ecol Monogr 66, 67-90.

16. Kim JH (1997) The role of herbivory, and direct and indirect interactions, in algal succession. $J$ Exp Mar Biol Ecol 217, 119-35.

17. McClanahan TR (1997) Primary succession of coralreef algae: Differing patterns on fished versus unfished reefs. J Exp Mar Biol Ecol 218, 77-102.

18. Mayakun J, Kim JH, Prathep A (2010) Effects of herbivory and the season of disturbance on algal succession in a tropical intertidal shore, Phuket, Thailand. Phycol Res 58, 88-96.

19. Lapointe BE (1999) Simultaneous top-down and bottom-up forces control macroalgal blooms on coral reefs. Limnol Oceanogr 44, 1586-92.

20. Lapointe BE, Littler MM, Littler DS (1997) Macroalgal overgrowth of fringing coral reefs at Discovery Bay, Jamaica: bottom-up versus top-down control. Proc 8th Int Coral Reef Symp 1, 927-32.

21. Lobban C, Harrison PJ (1994) Seaweed Ecology and Physiology. Cambridge Univ Press, New York.

22. Lapointe BE, Thacker K (2002) Community-based water quality and coral reef monitoring in the Negril Marine Park, Jamaica: land-based nutrient inputs and their ecological consequences. In: Porter JW, Porter KG (eds) The Everglades, Florida Bay, and Coral Reefs of the Florida Keys: An Ecosystem Sourcebook. CRC Press, Boca Raton, FL. pp 939-63.

23. Beach K, Walters L, Vroom P, Smith C, Coyer J, Hunter C (2003) Variability in the ecophysiology of Halimeda spp. (Chlorophyta, Bryopsidales) on Conch Reef, Florida Keys, USA. J Phycol 39, 633-43.

24. Vroom PS, Smith CM (2003) Life without cells. Biologist 50, 222-6.

25. van Tussenbroek BI, van Dijk JK (2007) Spatial and temporal variability in biomass and reproduction of psammophytic Halimeda incrassata (Bryopsidales, Chlorophyta) in a Caribbean reef lagoon. J Phycol 43, 69-77.

26. Vroom PS, Smith CM, Coyer JA, Walters LJ, Hunter CL, Beach KS, Smith JE (2003) Field biology of Hal- imeda tuna (Bryopsidales, Chlorophyta) across a depth gradient: comparative growth, survivorship, recruitment, and reproduction. Hydrobiologia 501, 149-66.

27. Sinutok S, Hill R, Doblin MA, Wuhrer R, Ralph PJ (2011) Warmer more acidic conditions cause decreased productivity and calcification in subtropical coral reef sediment-dwelling calcifiers. Limnol Oceanogr 56, 1200-12.

28. Lapointe BE (1981) The effects of light and nitrogen on growth, pigment content, and biochemical composition of Gracilaria folifera v. angustissima (Gigartimales, Rhodophyta). J Phycol 17, 90-5.

29. Hata H, Kato M (2003) Demise of monocultural algal farms by exclusion of territorial damselfish. Mar Ecol Progr 263, 159-67.

30. Fong P, Boyer KE, Kamer K, Boyle KA (2003) Influence of initial tissue nutrient status of tropical marine algae on response to nitrogen and phosphorus additions. Mar Ecol Progr 262, 111-23.

31. Smith JE, Smith CM, Vroon PS, Beach KL, Miller S (2004) Nutrient and growth dynamics of Halimeda tuna on Conch Reef, Florida Keys: Possible influence of internal tides on nutrient status and physiology. Limnol Oceanogr 49, 1923-36.

32. Mayakun J, Kim JH, Lapointe BE, Prathep A (2012) Gametangial characteristics in the sexual reproduction of Halimeda macroloba Decaisne (Chlorophyta: Halimedaceae). Songklanakarin J Sci Tech 34, 211-6.

33. Reed DC, Ebeling AW, Anderson TW, Anghera M (1996) Differential reproductive responses to fluctuating resources in two seaweeds with different reproductive strategies. Ecology 77, 300-16.

34. Larkum AWD, Salih A, Kühl M (2011) Rapid mass movement of chloroplasts during segment formation of the calcifying siphonalean green alga, Halimeda macroloba. PLoS ONE 6, e20841.

35. Dethier MN, Williams SL, Freeman A (2005) Seaweeds under stress: manipulated stress and herbivory affect critical life-history functions. Ecol Monogr 75, 403-18. 